\title{
ONLINE LEARNING IN THE LIBRARY AND INFORMATION SCIENCE EDUCATION DURING THE COVID-19
}

\section{Thoriq Tri Prabowo*, Nur Riani*, Fina Hanifa Hidayati*, Heru Sulistya*, \& Lalu Rudy Rustandi*}

*UIN Sunan Kalijaga Yogyakarta

Email: toriq.prabowo@uin-suka.ac.id

(Submitted: 08-06-2021, Revised: 16-10-2021, Accepted: 01-11-2021)

DOI: $10.24252 / v 9 i 2 a 6$

\begin{abstract}
ABSTRAK: Penelitian ini bertujuan untuk menguraikan praktik perkuliahan daring yang ideal selama pandemi covid-19 di Program Studi Ilmu Perpustakaan UIN Sunan Kalijaga. penelitian ini menggunakan pendekatan mix method (kuantitatif dan kualitatif). 92 responden mahasiswa mengisi kuesioner daring mengenai pembelajaran daring yang ideal menurut mereka. Tidak hanya mengisi kuesioner kuantitatif, responden tersebut juga diberikan kesempatan untuk memberikan alasan dari setiap jawaban yang diisikan. Pembelajaran daring di Program Studi Ilmu Perpustakaan UIN Sunan Kalijaga dilakukan sejak Maret 2020. Pelaksanaannya menggunakan aplikasi yang berbeda-beda setiap dosennya. Beberapa aplikasi yang paling banyak digunakan adalah: Whatsapp, Google Classroom, eLearning UIN Sunan Kalijaga, Aplikasi online meeting seperti Zoom, Google Meet, dan Webex, Youtube, dan aplikasi podcast seperti Anchor dan Spotify. Evaluasi pembelajaran daring menggunakan prinsip inklusivitas perlu untuk dilakukan.
\end{abstract}

Kata kunci: pembelajaran daring; pembelajaran inklusi; media pembelajaran; ilmu perpustakaan, covid-19

\begin{abstract}
This study aims to describe the proper online lecture practice during the pandemic Covid-19 in the Department of Library Science of UIN Sunan Kalijaga. This study uses a mixedmethod approach (quantitative and qualitative). 92 students as the respondents filled out online questionnaires about their proper online learning. Not only filling in a quantitative questionnaire, these respondents were also given to provide reasons for each filled answer. Online learning in the Department of Library Science of UIN Sunan Kalijaga has been conducted since March 2020. The implementation uses different applications for each lecturer. Some of the most widely used applications are Whatsapp, Google Classroom, eLearning UIN Sunan Kalijaga, online meeting applications such as Zoom, Google Meet, and Webex, Youtube, and podcast applications such as Anchor and Spotify. Evaluation of online learning using the principle of inclusiveness is necessary.
\end{abstract}

Keywords: online learning; inclusive learning; learning media; library science; covid-19

\section{INTRODUCTION}

The Coronavirus showed up for the first time in Wuhan, Tiongkok, in December 2019 which is medically known as the SARS Coronavirus 2 (SARS-COV-2). The infection of this virus is through droplets that come out of the human nose and mouth. The virus was announced as a pandemic 
because it has spread around the globe. According to World Health Organization (WHO), almost all countries in the world have been infected with the virus.

In responding to such a situation, many countries have then to set up rules like physical distance to prevent their citizens from being infected. So that working from home can be a good way to break the chain of the spread of the virus. The pandemic has been ruined normal life, messing up many aspects of our daily life. Likewise in the education sector. The learning process which is generally done face-to-face is fully replaced with online or distance learning (Fauzi \& Paiman, 2020). Virtual learning is conducted at every level of education.

One example is in the Department of Library Science, Faculty of Adab and Cultural Science in UIN Sunan Kalijaga Yogyakarta that has been implementing online learning since March, $16^{\text {th }}$ 2020 according to the university policy of the learning process during pandemic No. 53 the Year 2020. The department has a variety of students in diversity, ranging from ethnicity, religion, race, and differences in physical capabilities because it includes students with disabilities. The implementation of online learning is certainly a challenge for the department. Online learning in this context needs to be evaluated so that it is under the principles of universal design learning (UDL) and is effectively used by various students with various diversity (Mujiono et al., 2018).

The online learning system is one form of adaptation of the implementation of independent learning (Sari, 2013). Where independence in learning needs to be given to students so that they have the responsibility to manage and discipline themselves and in developing the ability to learn in their interests (Rivalina, 2013). The independence of learning itself can be seen from the presence or absence of opportunities given to students, for example in determining learning objectives, in choosing the methods and learning media used to achieve the objectives, and in determining the methods, tools, and evaluation criteria for learning outcomes (Putra, 2017).

As technology develops, there are many alternative implementations of online learning that can be used according to learning needs (Darmayanti et al., 2007). Some of the alternatives offered by technology include using WhatsApp Group, Google Classroom, Podcasts, Google Meet, and others. The concept of online learning emerged along with the rapid development of technology marked by the emergence of digital or electronic information sources such as e-books, e-journals, and others (Pohan, 2020).

Online learning is carried out to prevent the spread of Covid-19 (Dewi, 2020; Purwanto et al., 2020). However, its implementation is certainly not that easy, there are challenges in implementing it (Astini, 2020; Darmalaksana et al., 2020). Meanwhile, online learning management should be carried out under the principles of inclusive learning (Mujiono et al., 2018) and under the 1945 Constitution, Article 32 paragraph (1) which states "every citizen has the right to education". Based on the researchers' initial observations, it is known that each lecturer has different strategies, methods, and learning media. To formulate the ideal online learning system, it is necessary to research by curating opinions from lecturers and students through comprehensive research (Yoo et al., 2014). This research was conducted to determine the ideal online learning during the covid-19 pandemic at the Department of Library Science UIN Sunan Kalijaga Yogyakarta. This research is expected to be able to contribute to formulating inclusive online learning, especially in the limitations of meeting physically during the pandemic.

\section{PREVIOUS FINDINGS}

Reflective studies and scholarly works that try to formulate the ideal online learning and match the experiences of students in carrying out online learning during the COVID-19 pandemic are still relatively few. Most education experts or analysts still focus on evaluative and technical issues. Such studies are still dominantly carried out by educators, education analysts, and students at undergraduate and postgraduate levels. However, based on the search results, researchers found some study topics that used critical studies of the experiences of students and online learning during the COVID-19 pandemic. 
Zaharah, Galia Ildusovna Kirilova, dan Anissa Windarti (2020) examined the impact of the Covid-19 pandemic on learning activities. This research used a qualitative method with a study of literature by looking at the results of surveys and studies of literature, journals, and documents from several printed and electronic media and books related to teaching and social society, sociology, and anthropology. They found that the government's steps in issuing policies to the public are not to carry out activities outside the home, all work is done from home, including teaching and learning activities (Zaharah et al., 2020). In this study, there is no clear explanation of policies and teaching and learning processes with the existing education level categories, the researchers only discussed in general the impact of Covid-19 on teaching and learning activities. In addition, researchers have not presented solutions to the obstacles faced in teaching and learning activities.

Michael PA Murphy (2020) explained in his study the consequences of the securitization (restriction) policy of face-to-face learning in higher education to determine the pedagogy (educational landscape) after the covid-19 pandemic in Copenhagen. This study analyzes 25 emergency eLearning declarations in American universities with a securitization theory approach as an important tool for educators not only to observe (and understand) the eLearning emergency phenomenon but also to advocate for desecuritization of schools after the Covid-19 crisis has passed (Murphy, 2020). This research has not provided a clear picture of the post-pandemic landscape of higher education in Copenhagen.

Basilika Giorgi and David Kvavadze (2020) described the capacity of the country and its population to continue the education process in schools in the form of distance learning (online), then shows the platforms used by government support, such as the online portal, TV School, and the Microsoft team for public schools and other alternatives such as Zoom, Slack and Google Meet, an EduPage platform that can be used for online education and live communication and provides examples of its use along with a review of the various platforms available. Their study engaged 950 private students as respondents. Their findings indicated that the rapid transition to this form of online education was successful and the experience gained can be used in the future. Online experience and study can be useful for other countries that haven't figured out how to transition (Basilaia \& Kvavadze, 2020).

Learning at a glance is seen as a process that runs routinely without a conceptual plan (Abdullah B , 2017). In fact, learning is a process of developing knowledge, skills, or attitudes as a person's interaction with information and his environment so that in the learning process it is necessary to select, compile and deliver information in an appropriate environment and through the interaction of the learner with his environment (Heinich et al., 1999). The learning process experienced throughout human life can be applied anywhere and anytime (Ahmad, 2018), (Rahayu \& Widodo, 2017). Learning has a similar meaning to teaching, although it has a different connotation (Pane \& Dasopang, 2017). In the context of education, teachers teach that students can learn and master the content of lessons to achieve a specified goal (cognitive aspect), which can also influence changes in attitudes (affective aspects), and skills (psychomotor aspects) of a student (Hamzah, 2012). Teaching gives the impression as the work of one party, namely the work of the teacher only. While learning also implies interaction between teacher and students (Jack Lam, 2005).

The learning today, interactions between students and teachers do occur, but through virtual, virtual worlds, or interactions occur using technological tools or devices such as computers, notebooks, and cell phones (Muirhead, 2000; Small et al., 2012; Yoo et al., 2014). Learning during the pandemic using online learning applications (online) (Basilaia \& Kvavadze, 2020). This online learning was originally a solution to distance learning that offered flexibility in terms of place and time of study as a result of globalization (Muirhead, 2000). The idea of inclusive online learning emerged instantly because the learning involved various parties with ethnic, religious, racial, cultural, capability, citizenship, and other diversity backgrounds. The 
demographic composition that contains various diversity is an aspect that must be considered to create inclusive online learning (Rutherford \& Kerr, 2008).

Inclusive learning will be succeeded if learning is carried out evenly, closing existing gaps, and creating harmony in diversity (Walker et al., 2019). One of the successes of this education is shown by the birth of learners who do not judge the differences that exist around them.

On the Center for Teaching and Learning website to create inclusive learning, it is necessary to pay at least five principles (Columbia CTL, 2020). The five principles include: fostering a sense of collective ownership; knowing the expectations of students explicitly; learning content that recognizes the diversity and is open to criticism and suggestions; learning design that can be followed with various accessibility; and reflecting the commitment to online learning that is oriented towards inclusive values.

\section{RESEARCH METHODOLOGY}

This research is a descriptive study with a mixed-method approach (quantitative and qualitative). Quantitative data was collected using a questionnaire using Google Form (https://forms.gle/tgqNqmEPXAhBKfGj9). The qualitative data were obtained by participatory observation, structured interviews conducted through online applications, and documentation by observing various documents related to the issues studied. The qualitative data support the quantitative one obtained through the questionnaire which was filled in by 92 respondents/students. Meanwhile, the interview with informants was conducted with a representative of 92 respondents. The results of the analysis of the collected quantitative and qualitative data were transcribed into a narrative to be analyzed and drawn conclusions.

\section{RESULTS AND FINDINGS ANALYSIS}

\section{Online learning overview in the department}

Since March $16^{\text {th }}, 2020$, UIN Sunan Kalijaga has implemented online learning, including in the Department of Library Science. However, the learning methods that take place on campus are not diverse. There have been several variations of learning methods since then.

Based on the results of the survey, it is known that the tools used for online learning are: 73.9\% smartphone, $21.7 \%$ laptop, $2.2 \%$ PC, and 2.2\% combination between smartphone and laptop. Furthermore, the type of internet quota used $77.2 \%$ personal data quota, $20.6 \% \mathrm{WiFi}$ subscribed by family at home, $2.2 \%$ WiFi subscribed by dormitory owner. As for the estimated consumption of the internet data quota, the average internet quota for online learning per month is 7.16 gigabytes. The average amount of money spent to buy or rent the internet data quota is $\mathrm{Rp}$. 72,000 . If this data is juxtaposed with the nominal pulse given by the university to every student in the amount of around 12-15 GB, then indeed the assistance given by the university can be said sufficient for every student. However, based on several random interviews, it is known that this amount could be insufficient if online lectures are conducted using applications that tend to require a large internet data quota, such as online meeting applications for example Zoom, Google Meet, Webex, and the like. In addition, the availability of several educational packages which are the result of collaboration between the campus and internet providers is also felt to be quite helpful.

Based on observations, it is known that during the covid-19 pandemic several applications were used for online learning. Some of these applications include Google Classroom; WhatsApp; Telegram; eLearning UIN Sunan Kalijaga; Online meeting applications such as Google Meet, Zoom, Webex, and so on; Podcast apps like Anchor and Spotify; YouTube; Kahoot, and Quizizz. Each of these applications has its advantages and disadvantages. This is expected to be able to prepare more mature online learning and introduce other, more varied applications to lecturers and students. 
Effectiveness of online learning applications, methods, and evaluations

For attendance purposes, below are the percentages of student answers regarding the types of applications that they think are effective:

Table 1. Respondents' responses of the effective applications for attendance purposes

\begin{tabular}{clc}
\hline No & \multicolumn{1}{c}{ Applications } & $\mathbf{\%}$ \\
\hline 1. & Google Classroom & $47,8 \%$ \\
2. & WhatsApp & $41,3 \%$ \\
3. & eLearning UIN Sunan Kalijaga & $5,4 \%$ \\
4. & Online application meetings like Google Meet, & $4,3 \%$ \\
& Zoom, Webex, and so on & $1,1 \%$ \\
\hline
\end{tabular}

Google classroom and WhatsApp become the most used among other applications in terms of attendance purposes. This is due to the reason for calculating the real-time and notifications obtained from the two applications. The UIN Sunan Kalijaga eLearning application which is integrated with the academic information system was chosen by the number of students which is not significant when compared to the two applications mentioned earlier. The small responses of students who choose the eLearning application at UIN Sunan Kalijaga are suspected because this application is rarely used for online lectures.

Furthermore, it is related to applications that are suitable for delivering courses materials. Below shows students' responses regarding applications that they consider effective for delivering course materials.

Table 2. Respondents' responses of the effective applications for delivering course materials

\begin{tabular}{clc}
\hline No & \multicolumn{1}{c}{ Applications } & $\mathbf{\%}$ \\
\hline 1. & Google Classroom & $27,2 \%$ \\
2. & WhatsApp & $47,8 \%$ \\
3. & eLearning UIN Sunan Kalijaga & $2,2 \%$ \\
4. & Online meeting applications like Google Meet, & $10,9 \%$ \\
& Zoom, Webex, and so on & $7,6 \%$ \\
5. & Podcasts like Anchor and Spotify & $1,1 \%$ \\
6. & Video uploaded on YouTube & $3,2 \%$ \\
7. & Combination of two or more different & \\
\hline
\end{tabular}

Why WhatsApp has become so convenient to use, among others; familiar, easy to use, saves internet data quota, does not require a relatively fast internet connection, and allows not only text sharing but also multimedia; can display images, sound, and even video. The next application that is quite interesting for students is Google Classroom. According to them, Google Classroom is effective because it is relatively easy to use; course materials can be seen clearly, especially related to material classification and material history; relatively does not require data quota and high internet speed; there is a clear time limit along with real-time notifications, and allows to upload file attachments. Then, the online meeting application applications such as Google Meet, Zoom, Webex, and so on were chosen because of the opportunity for direct interaction such as during face-to-face lectures. However, there are not many students who wanted lectures to use such 
applications because they require a fairly large internet data quota consumption and require a stable speed. The podcast and video application uploaded on the YouTube channel was chosen by a small number of students because of the narrative explanation and the opportunity to listen to it while doing other works. Some respondents also felt that the combination of applications was quite effectively used to deliver lecture materials. The two most frequently mentioned applications are a combination of Google Classroom and WhatsApp.

For question-and-answer ( $\mathrm{Q} n \mathrm{~A})$ purposes during online learning, several applications were chosen by the respondents. Here are their answers.

Table 3. Respondents' responses of the effective applications for $\mathbf{Q} \mathrm{n}$ A purposes

\begin{tabular}{clc}
\hline No & \multicolumn{1}{c}{ Applications } & $\mathbf{\%}$ \\
\hline 1. & Google Classroom & $25 \%$ \\
2. & WhatsApp & $67,4 \%$ \\
3. & eLearning UIN Sunan Kalijaga & $0 \%$ \\
4. & Online meeting applications like Google Meet, & $6,5 \%$ \\
& Zoom, Webex, and so on & $0 \%$ \\
5. & Podcasts like Anchor and Spotify & $1,1 \%$ \\
6. & Telegram & \\
\hline
\end{tabular}

WhatsApp is the most used for Q n A purposes during the lecturers. Some reasons include: familiar with the apps, there is a name tag feature or answers directly to the intended person, it is relatively efficient on internet data quota, and relatively does not require high-speed internet. However, this application has the disadvantage that the question-and-answer process is often interrupted because questions and answers are buried by other chats in the group. Google Classroom was chosen for some reasons like there is a special menu for discussion, not buried with comments as in the WhatsApp group, relatively efficient internet data quota, relatively does not require high-speed internet. Furthermore, online meeting applications such as Google Meet, Zoom, Webex, and so on were chosen because of interactive direct interactions such as face-toface. Another application, almost similar to WhatsApp as a chat application platform, Telegram was chosen by a small number of students for reasons of application stability and the lack of storage space in the internal memory. For Q n A purposes, it seems that the eLearning of UIN Sunan Kalijaga needs to be evaluated because none of the respondents wanted this application. This is probably because the application based on web services often requires a refresh or reload to find out new questions and answers. The respondents feel that questions and answers are not delivered in real-time. The podcast application and YouTube channel were not selected because these applications only send information in one direction.

Finally, regarding the effectiveness of an application for evaluating online learning, below is the percentage of student answers regarding applications that they think are effective to use:

Table 4. The most effective application for online learning

\begin{tabular}{clc}
\hline No & \multicolumn{1}{c}{ Applications } & \% \\
\hline 1. & Google Classroom & $60,9 \%$ \\
2. & WhatsApp & $27,2 \%$ \\
3. & eLearning UIN Sunan Kalijaga & $0 \%$ \\
4. & Online meeting applications like Google Meet, & $0 \%$ \\
& Zoom, Webex, and so on & $0 \%$ \\
5. & Podcasts like Anchor and Spotify & $0 \%$ \\
6. & Video uploaded on YouTube & $11,9 \%$ \\
7. & Web-based quiz apps like Kahoot and Quizizz & \\
\hline
\end{tabular}


Google Classroom was widely chosen for several reasons including a variety of quizzes and exam questions, confidentiality of answers collected, clear duration of time, notifications. It was followed by WhatsApp for almost the same reasons. However, this application has the disadvantage that the question-and-answer process is often interrupted because questions and answers are buried by other chats in the WhatsApp group. Besides WhatsApp, a few students also choose other chat applications such as Telegram. Furthermore, web-based quiz applications such as Kahoot, Quizizz, and the like were chosen because they were interactive, interesting, and have entertaining games. eLearning UIN Sunan Kalijaga must evaluate the features or menus because none of the respondents have chosen it. It can be seen that online meeting applications such as Google Meet, Zoom, Webex, Anchor, Spotify, and others are also not widely chosen.

\section{DISCUSSION}

Based on the results of the questionnaire, it is known that during the pandemic, online learning received various responses, either positive or negative views. As for some of these responses, namely: $5.4 \%$ could not accept; $59.8 \%$ quite accept; $30.4 \%$ can accept; and $4.3 \%$ were very receptive. According to respondents' answers, with the unpreparedness of both lecturers and university to carry out online lectures, the learning processes are nothing more than giving assignments online. The implementation of online learning without preparation and in-depth assessment of the capabilities of lecturers and students then creates gaps, especially in terms of accessibility.

Regarding the comparison of lecture time online and face-to-face which includes the proportion of study time, assignments and so on, the respondents answered $6.5 \%$ very inappropriate; $18.5 \%$ is not suitable; $47.8 \%$ is quite appropriate; $23.9 \%$ matched; and $3.3 \%$ is very appropriate. Working from home scheme created the illusion of working time and hours. The integrity of the learning participants, both from the lecturers' and students' perspectives, becomes difficult to measure so that their enthusiasm becomes the same. There needs to be a correction and evaluation in terms of the timing of this online learning implementation. The length of this online learning needs to be adjusted so that it does not interfere with health, especially eye health because the eyes are required to stare at the device for a long time. Not only during lectures but also when doing assignments. The absence of physical meetings that create confusion often makes online lectures not on time.

Regarding the delivery of the course materials presented by the lecturer to students at each meeting, the respondents answered $5.4 \%$ very inappropriately; $25 \%$ not feasible; $37 \%$ quite worthy; $26.1 \%$ eligible; and $6.5 \%$ very decent. Students want a variety of explanations, such as face-to-face lectures. Students feel that online lectures that are only realized by giving online and massive assignments are very burdensome, even counterproductive. Learning that is carried out using media and technology is expected to be fulfilled by creative materials and delivery. Students also feel that practical classes are very difficult to carry out during this pandemic. They worry that practical skills cannot be fulfilled if learning continues in a virtual space. The development of teaching materials that are synergized with various online learning materials will bring students to study independently and at the same time gain the basic competencies expected by the institution.

Finally, when respondents were asked about the possibility that online learning would continue even after the pandemic ended, their answers were $10.9 \%$ strongly disagree; $22.8 \%$ disagree; $30.4 \%$ quite agree; $27.2 \%$ agree; and $8.7 \%$ strongly agree. Based on that data, of course, online learning that has been carried out for several months since the pandemic is not the best practice. It was also found from another study that the respondents were quite capable of using their devices to access and identify the validity of information spread on the internet (Jannana, Prabowo, \& Istriyani, 2021). This data shows that UIN Sunan Kalijaga Library Science students are quite capable of adapting to the online learning process during the pandemic. There are still some 
things to evaluate. The evaluation instrument is inclusiveness. The state and educational institutions need to understand the conditions of students and their families. These conditions include economic conditions, digital infrastructure, as well as physical conditions related to accessibility.

\section{CONCLUSION}

The ideal online learning at the Department of Library Science UIN Sunan Kalijaga Yogyakarta is a collective effort, either by lecturers, students, or the university itself. The economic gap and digital infrastructure are the homework of various parties. The implementation of online learning is then not only a matter of infrastructure but requires wisdom. The online learning format, which is often translated into an online assignment, needs to pay attention to student abilities. Especially those courses that have a fairly large credit load.

Online learning applications do offer a variety of different features. Learning about the pros and cons is one of the best ways to optimize the app, regardless of the platform. Focusing on only one thing that is highlighted by one of the online learning applications has the potential to have disproportionate side effects on other things, for example learning using online meeting applications such as Zoom, Google Meet, Webex and so on does make online learning like face-toface learning, but this is not wise for students who have difficulty getting internet access.

Internet data quota assistance for students and the training on the use of online learning applications by the university for lecturers are good efforts to prepare for better online learning in the future. A road map related to online learning and risk management in providing education in times of pandemics based on inclusive principles needs to be prepared immediately. This is important to minimize the occurrence of gaps in the implementation of learning. Furthermore, the implementation of online learning after the pandemic also needs to be reviewed so that the implementation of online learning becomes more effective, not counterproductive. The concept of "learning without wall class" becomes relevant and finds its urgency to be applied immediately.

\section{REFERENCES}

Abdullah, B. (2017). Jurnal Makna Pembelajaran dalam Pendidikan. Istiqra`: Jurnal Pendidikan Dan Pemikiran Islam, 5(1), Article 1. http://www.umpar.ac.id/jurnal/index.php/istiqra/article/view/490

Ahmad, T. (2018). Mobile Phones as A Learning Tool: A Lecturer's Viewpoint. Society and Business Review, 13(2), 132-139. https://doi.org/10.1108/SBR-03-2018-0021

Astini, N. K. S. (2020). Tantangan dan Peluang Pemanfaatan Teknologi Informasi dalam Pembelajaran Online Masa Covid-19. Cetta: Jurnal Ilmu Pendidikan, 3(2), 241-255. https://doi.org/10.37329/cetta.v3i2.452

Basilaia, G., \& Kvavadze, D. (2020). Transition to Online Education in Schools during a SARS-CoV2 Coronavirus (COVID-19) Pandemic in Georgia. Pedagogical Research, 5(4), em0060. https://doi.org/10.29333/pr/7937

Columbia CTL. (2020, April 6). Inclusive Teaching and Learning Online. Columbia CTL. https://ctl.columbia.edu/resources-and-technology/teaching-withtechnology/teaching-online/inclusive-teaching/

Darmalaksana, W., Hambali, R. Y. A., Masrur, A., \& Muhlas, M. (2020). Analisis Pembelajaran Online Masa WFH Pandemic Covid-19 sebagai Tantangan Pemimpin Digital Abad 21. Karya Tulis Ilmiah (KTI) Masa Work From Home (WFH) Covid-19 UIN Sunan Gunung Djati Bandung, 1-12.

Darmayanti, T., Setiani, M. Y., \& Oetojo, B. (2007). E-learning pada Pendidikan Jarak Jauh: Konsep yang Mengubah Metode Pembelajaran di Perguruan Tinggi di Indonesia. Jurnal Pendidikan Terbuka Dan Jarak Jauh, 8(2), 99-113. 
Thoriq Tri Prabowo, Nur Riani, Fina Hanifa Hidayati, Heru Sulistya, \& Lalu Rudy Rustandi. Online Learning in the Library and Information Science Education During the Covid-19

Dewi, W. A. F. (2020). Dampak COVID-19 terhadap Implementasi Pembelajaran Daring di Sekolah Dasar. Edukatif: Jurnal Ilmu Pendidikan, 2(1), 55-61. https://doi.org/10.31004/edukatif.v2i1.89

Fauzi, M. A., \& Paiman, N. (2020). Covid-19 Pandemic in Southeast Asia: Intervention and Mitigation Efforts. Asian Education and Development Studies, ahead-of-print(ahead-ofprint). https://doi.org/10.1108/AEDS-04-2020-0064

Hamzah, S. H. (2012). Aspek Pengembangan Peserta Didik: Kognitif, Afektif, Psikomotorik. Dinamika Ilmu, 12(1), Article 1. https://doi.org/10.21093/di.v12i1.56

Heinich, R., Russell, J. D., Molenda, M., \& Smaldino, S. E. (1999). Instructional Media and Technologies for Learning. Prentice Hall.

Jack Lam, Y. L. (2005). School Organizational Structures: Effects on Teacher and Student Learning. Journal of Educational Administration, 43(4), 387-401. https://doi.org/10.1108/09578230510605432

Jannana, N. S., Prabowo, T. T. \& Istriyani, R. (2021). Identifying Fake News: A Lesson from Library Science Students. Khizanah al-Hikmah: Jurnal Ilmu Perpustakaan, Informasi, dan Kearsipan, 9(1), in press. https://doi.org/10.24252/v9i1a7

Mizumoto, K., Kagaya, K., \& Chowell, G. (2020). Early Epidemiological Assessment of the Transmission Potential and Virulence of Coronavirus Disease 2019 (COVID-19) in Wuhan City: China, January-February, 2020. MedRxiv, 2020.02.12.20022434. https://doi.org/10.1101/2020.02.12.20022434

Muirhead, W. D. (2000). Online Education in Schools. International Journal of Educational Management, 14(7), 315-324. https://doi.org/10.1108/09513540010378969

Mujiono, M., Degeng, I. N. S., \& Praherdhiono, H. (2018). Pengembangan Pembelajaran Sistem Blended Berbasis Universal Design for Learning untuk Kelas Inklusif. Jurnal Pendidikan: Teori, Penelitian, dan Pengembangan, 3(6), 758-763. https://doi.org/10.17977/jptpp.v3i6.11163

Murphy, M. P. A. (2020). Covid-19 and Emergency eLearning: Consequences of the Securitization of Higher Education for Post-Pandemic Pedagogy. Contemporary Security Policy, 41(3), 492-505. https://doi.org/10.1080/13523260.2020.1761749

Pane, A., \& Dasopang, M. D. (2017). Belajar dan Pembelajaran. Fitrah:Jurnal Kajian Ilmu-Ilmu Keislaman, 3(2), 333-352. https://doi.org/10.24952/fitrah.v3i2.945

Pohan, A. E. (2020). Konsep Pembelajaran Daring Berbasis Pendekatan Ilmiah. CV. Sarnu Untung.

Purwanto, A., Pramono, R., Asbari, M., Hyun, C. C., Wijayanti, L. M., Putri, R. S., \& Santoso, priyono B. (2020). Studi Eksploratif Dampak Pandemi COVID-19 Terhadap Proses Pembelajaran Online di Sekolah Dasar. EduPsyCouns: Journal of Education, Psychology and Counseling, 2(1), 1-12.

Putra, R. A. (2017). Penerapan Metode Pembelajaran Mandiri dalam Meningkatkan Hasil Belajar Peserta Didik (Studi pada Program Pendidikan Kesetaraan Paket C di PKBM Bina Mandiri Cipageran). Jurnal Pendidikan Luar Sekolah, 13(1), Article 1. https://ejournal.upi.edu/index.php/pls/article/view/8723

Rahayu, U., \& Widodo, A. (2017). Pengembangan Tutorial Online yang Mengintegrasikan Panduan Belajar Mandiri untuk Melatih Self-Regulated Learning. Jurnal Pendidikan dan Kebudayaan, 2(2), 201-210. https://doi.org/10.24832/jpnk.v2i2.676

Rivalina, S. S. dan R. (2013). Perkembangan Pendidikan Terbuka dan Jarak Jauh di Indonesia. Jurnal Teknodik, O(0), 59-72. https://doi.org/10.32550/teknodik.v0i0.8

Rutherford, A. G., \& Kerr, B. (2008). An Inclusive Approach to Online Learning Environments: Models and Resources. In Online Submission (Vol. 9, Issue 2, pp. 64-85). https://eric.ed.gov/?id=ED501110

Sari, A. R. (2013). Strategi Blended Learning untuk Peningkatan Kemandirian Belajar dan Kemampuan Critical Thinking Mahasiswa di Era Digital. Jurnal Pendidikan Akuntansi Indonesia, 11(2), Article 2. https://doi.org/10.21831/jpai.v11i2.1689 
Small, F., Dowell, D., \& Simmons, P. (2012). Teacher Communication Preferred Over Peer Interaction: Student Satisfaction with Different Tools in a Virtual Learning Environment. Journal of International Education in Business, 5(2), 114-128. https://doi.org/10.1108/18363261211281735

Walker, J., Pearce, C., Boe, K., \& Lawson, M. (2019). The Power of Education to Fight Inequality. Oxfam.

Yoo, S., Jeong, K. H., \& Young, K. S. (2014). Between Ideal and Reality: A Different View on OnlineLearning Interaction in a Cross-National Context. Journal for Multicultural Education, 8(1), 13-30. https://doi.org/10.1108/JME-04-2013-0018

Zaharah, Z., Kirilova, G. I., \& Windarti, A. (2020). Impact of Corona Virus Outbreak Towards Teaching and Learning Activities in Indonesia. Salam: Jurnal Sosial Dan Budaya Syar-i, 7(3), 269-282. https://doi.org/10.15408/sjsbs.v7i3.15104 